\title{
APLIKASI LIMBAH CAIR PABRIK KELAPA SAWIT DENGAN METODA BIOPORI TERHADAP PERTUMBUHAN TANAMAN KELAPA SAWIT (ELAEIS GUINEENSIS JACQ.) BELUM MENGHASILKAN
}

\author{
Demson Saputra Tambunan', Nelvia Nelvia', Al Ichsan Amri ${ }^{1}$ \\ ${ }^{1}$ Jurusan Agroteknologi, Fakultas Pertanian, Universitas Riau \\ Kampus Binawidya, Universitas Riau \\ Jl. H.R. Soebrantas Km. 12,5 Panam Pekanbaru Riau, Indonesia, 28293 \\ Email:demson123@gmail.com.Mobile:+6282175114694
}

\begin{abstract}
The wider the area of oil palm plantations in Indonesia, the more palm oil mills will process more oil palm fruit bunches and produce waste one of them is liquid waste. The amount of liquid waste that is more and more if not treated properly will cause environmental pollution. The research aim to study the effect of liquid waste of oil palm factory (LWOPF) with biopori method to the growth of immature oil palm plant. The experiment was conducted in oil palm plantation of Agricultural Faculty of Riau University from May to July 2017. The experiment was arrange drandomized complete design consisting of 13 treatments (without LWOPF; 5; 7.5 and 10 liters LWOPFeachapplied in 1, 2, 3 and 4 biopore/plants), each repeated three times. The parameters observed were plant height, number of midrib, length of midrib, number of leaves, width and length of leaves. The results showed that the application ofLWOPF dose 7.5 liters applied in 4 biopore holes / plants increased addition the number of midrib and the leaves, the width and length of the leaves compared to without LWOPF and the highest than another treatment, but the addition of plant high increased at doses 7.5 liters in 3 biopore/plant and highest than another treatment.
\end{abstract}

Key words : Liquid Wastes of Oil Palm Factory, Biopore Holes, Oil Palm Plants

(C) 2019 Demson Saputra Tambunan, Nelvia Nelvia, Al Ichsan Amri

\section{PENDAHULUAN}

Kelapa sawit merupakan salah satu tanaman perkebunan yang memiliki nilai ekonomi tinggi dan berkembang pesat. Semakin luasnya areal perkebunan kelapa sawit di Indonesia maka jumlah pabrik kelapa sawit akan semakin banyak mengolah tanda buah segar kelapa sawit dan menghasilkan limbah dari hasil olahan kelapa sawit yaitu limbah padat dan limbah cair. Setiap ton tandan buah segar (TBS) yang diolah di pabrik akan berpotensi menyisakan limbah sekitar $23 \%$ tandan kosong kelapa sawit, $4 \%$ wet decanter solid, 6,5\% cangkang, $13 \%$ serabut dan 50\% limbah cair ( Direktorat pengolahan hasil pertanian, 2006)

Limbah cair pabrik kelapa sawit (LCPKS) merupakan bahan organik yang mengandung hara yang diperlukan tanaman, oleh karena itu aplikasi limbah cair tersebut merupakan usaha daur ulang sebagian hara (nutrient recycling) yang terikut melalui panen tandan buah segar (TBS) kelapa sawit, sehingga akan mengurangi biaya pemupukan yang tergolong sangat tinggi untuk budidaya tanaman kelapa sawit (Nainggolan, 2002).

Limbah cair pabrik kelapa sawit berwarna kecoklatan, terdiri dari padatan terlarut dan tersuspensi berupa koloid dan residu minyak dengan kandungan COD dan BOD tinggi sekitar $68.000 \mathrm{ppm}$ dan 27.000 ppm, bersifat asam( $\mathrm{pH}$ nya 3,5-4), terdiri dari $95 \%$ air, 4-5 \% bahan-bahan terlarut dan tersuspensi (selulosa, protein, lemak) dan 0,5-1 \% residu minyak yang sebagian besar berupa emulsi. Kandungan total suspended 
solid LCPKS tinggi sekitar 1.330-50.700 mg/L, tembaga $(\mathrm{Cu})$ 0,89 ppm, besi $(\mathrm{Fe})$ 46,5 ppm dan seng (Zn) 2,3 ppm serta amoniak 35 ppm (Ma,2000). Menurut Baharudin et al.(2009) kandungan LCPKS terdiri dari bahan organik biodegradable denga konsentrasi yang tinggi seperti lemak, protein dan selulosa yang akan mempengaruhi kandungan oksigen terlarut dan padatan tersuspensi.

Limbah kelapa sawit mempunyai beberapa manfaat seperti yang dinyatakan oleh Widhiastuti et al. (2006) yaitu dapat dijadikan pupuk karena pemberian LCPKS pada lahan perkebunan kelapa sawit dapat meningkatkan sifat fisik dan kimia tanah, meningkatkan biodiversitas tumbuhan penutup tanah, meningkatkan biodiversitas makrofauna dan mikro fauna tanah.

Pengaplikasian lubang resapan biopori dengan cara menggali tanah secara vertikal dengan kedalaman (30-100) $\mathrm{cm}$ tidak lebih melebihi kedalaman air tanah dengan diameter (10-30) $\mathrm{cm}$. Lubang resapan digali dengan menggunakan bor biopori agar diameter yang dihasilan seragam kemudian lubang diisi limbah-limbah organik (Brata, 2008).

Hasil penelitian Askrindayani (2006) aplikasi limbah cair pabrik kelapa sawit di perkebunan kelapa sawit dengan jarak tanam $9,2 \mathrm{~m} \times 7,8 \mathrm{~m}$ yang menerapkan Land Aplication berukuran $100 \mathrm{~m} \times 0,5 \mathrm{~m}$ dan jarak dari tanaman $8,75 \mathrm{~m}$ pada jarak $60 \mathrm{~cm}$ dapat meningkatkan $\mathrm{pH}$ tanah, dan dapat meningkatkan kesuburan tanah dengan tersedianya unsur-unsur hara yang dibutuhkan tanaman dan memperbaiki sifat tanah namun semakin jauh jarak Land Aplication maka Ntotal tanah, P- tersedia, K-tukar tanah dan KTK tanah semakin menurun.

Berdasarkan hasil penelitian Tambunan (2016) bahwa aplikasi limbah cair pabrik kelapa sawit dengan metoda biopori pada umur 21 bulan sampai 24 bulan berpengaruh terhadap pertumbuhan tanaman kelapa sawit belum menghasilkan dan mendapatkan dosis yang sesuai yaitu dengan dosis 5 liter limbah cair pabrik kelapa sawit.

\section{BAHAN DAN METODA}

Penelitian dilaksanakan di kebun kelapa sawit Fakultas Pertanian Universitas Riau, Pekanbaru dari bulan Mei 2017 sampai bulan Juli 2017. Limbah cair kelapa sawit berasal dari kolam aerobik pada kolam pengolahan limbah PTPN V Sei Pagar. Pipa paralon yang digunakan berukuran diameter $12,7 \mathrm{~cm}$ dengan panjang $40 \mathrm{~cm}$. Penelitian dilakukan dilahan yang memiliki jenis tanah Inceptisol Penelitian dilaksanakan secara eksperimen menggunakan rancangan acak lengkap terdiri dari 13 perlakuan( tanpa LCPKS; 5; 7,5 dan 10 liter LCPKS masingmasing diberikan dalam 1, 2, 3 dan 4 lubang biopori/tanaman) setiap perlakuan diulang tiga kali. Hasil analisis LCPKS adalah dimana unsur $\mathrm{N}=675 \mathrm{mg} / \mathrm{l}, \mathrm{P}=90-110 \mathrm{mg} / \mathrm{l}, \mathrm{K}=$ $1.000-1.875 \mathrm{mg} / \mathrm{l}$ dan $\mathrm{Mg}=250-320 \mathrm{mg} / \mathrm{l}$.

Pengamatan yang dilakukan adalah tinggi tanaman $(\mathrm{cm})$, jumlah pelepah, panjang pelepah $(\mathrm{cm})$, lebar anak daun $(\mathrm{cm})$, jumlah anak daun dan panjang anak daun $(\mathrm{cm})$.

Pengukuran tinggi tanaman kelapa sawit menggunakan alat Vertex Transporder. Cara kerja alat tersebut adalah pertama transponder harus ditempatkan di $\mathrm{T}$ height atau (tinggi transponder) yang telah diatur dalam menu pengaturan, lalu letakkan transponder ke arah tanaman yang akan diukur kemudian berjalanlah dengan jarak yang sesuai dari objek atau tanaman kelapa sawit yang akan diukur. Pengamatan jumlah pelepah daun dilakukan dengan menghitung jumlah pelepah daun yang telah membuka sempurna. Pada Pengamatan panjang pelepah daun dilakukan dengan mengukur pelepah daun kesembilan.

Pengukuran lebar anak daun dilakukan dengan cara mengukur lebar anak daun pada pelepah daun kesembilan. Pengukuran ini dilakukan pada dua anak daun yang berada di kiri dan kanan daerah ekor kadal menggunakan alat meteran. Pengamatan jumlah daun dengan menghitung daun yang telah membuka sempurna.

Pengukuran panjang anak daun dilakukan dengan cara mengukur panjang anak daun pada pelepah kesembilan. 
Untuk masing-masing pengamatan, pengukuran dilakukan sebanyak dua kali yaitu pengukuran awal dan pengukuran akhir. Pengukuran awal dilakukan pada umur tanaman 30 bulan dan pengukuran akhir pada umur tanaman 32 bulan. Data yang diperoleh dari hasil pengukuran dianalisis secara statistik menggunakan sidik ragam model linear.

\section{HASIL DAN PEMBAHASAN \\ Pertambahan Tinggi Tanaman}

Tabel 1 menunjukkan bahwa pemberian LCPKS dosis 5,0 liter dengan satu lubang, dua lubang, tiga lubang dan empat lubang biopori/tanaman meningkatkan pertambahan tinggi tanaman sekitar tiga sampai empat kali dan peningkatannya lebih besar yaitu lima sampai delapan kali bila dosisnya ditingkatkan hingga 7,5 liter dan pada dosis 10,0 liter peningkatan pertambahan tinggi tanaman cenderung menurun yaitu lima sampai enam kali dibandingkan tanpa perlakuan. Adapun pertambahan tinggi tanaman tertinggi diperoleh pada pemberian LCPKS dosis 7,5 liter dengan 3 lubang biopori/tanaman. Hal ini disebabkan adanya perbaikan sifat-sifat fisik, kimia dan biologi tanah akibat pemberian LCPKS.

Tabel 1. Pertambahan tinggi tanaman kelapa sawit setelah pemberian LCPKS dengan metoda biopori pada umur $30-32$ bulan

Dosis LCPKS dan lubang resapan biopori/tanaman $\quad$ Pertambahan tinggi tanaman

$(\mathrm{cm})$

Tanpa perlakuan

6,33 e

LCPKS dosis 5,0 liter dengan 1 lubang biopori/tanaman

$20,66 \mathrm{~d}$

LCPKS dosis 5,0 liter dengan 2 lubang biopori/tanaman

$22,66 \mathrm{~d}$

LCPKS dosis 5,0 liter dengan 3 lubang biopori/tanaman

$23,33 \mathrm{~d}$

LCPKS dosis 5,0 liter dengan 4 lubang biopori/tanaman

$24,33 \mathrm{~d}$

LCPKS dosis 7,5 liter dengan 1 lubang biopori/tanaman

$34,33 \mathrm{c}$

LCPKS dosis 7,5 liter dengan 2 lubang biopori/tanaman

$41,66 \mathrm{~b}$

LCPKS dosis 7,5 liter dengan 3 lubang biopori/tanaman

49,33 a

LCPKS dosis 7,5 liter dengan 4 lubang biopori/tanaman

$43,33 \mathrm{~b}$

LCPKS dosis 10,0 liter dengan 1 lubang biopori/tanaman

$43,33 \mathrm{~b}$

LCPKS dosis 10,0 liter dengan 2 lubang biopori/tanaman

$41,66 \mathrm{~b}$

LCPKS dosis 10,0 liter dengan 3 lubang biopori/tanaman

$41,33 \mathrm{~b}$

LCPKS dosis 10,0 liter dengan 4 lubang biopori/tanaman

$39,00 \mathrm{~b}$

Angka-angka pada kolom yang diikuti oleh huruf kecil yang sama adalah berbeda nyata menurut uji DNMRT pada taraf 5\%.

Semakin banyak biopori maka penyebaran LCPKS didalam tanah semakin luas dan merata.Adapun LCPKS dalam tanah berperan untuk memperbaiki sifat sifat fisik dan kimia tanah, meningkatkan biodiversitas tumbuhan penutup tanah, meningkatkan biodiversitas makrofauna dan mikro fauna tanah.(Widhiastuti et. al , 2006). Salah satu perbaikan sifat fisik tanah yang terjadi yaitu dimana kemampuan tanahdalam menyerap air semakin baik sehingga tekstur tanah menjadi bagus. Kandungan COD dan BOD yang tinggi pada LCPKS dapat menyediakan unsur hara yang dibutuhkan oleh tanah sehingga kandungan C-organik dalam tanah terpenuhi, dimana kandungan C-organik mampu meningkatkan kapasitas tukar kation . Hal ini sesuai dengan pendapat Sutanto (2006) yang menyatakan bahwa dengan adanya penambahan bahan organik, sifat fisik, biologi dan kimia tanah menjadi lebih baik.

Peningkatan Pertambahan tinggi tanaman tersebut sangat dipengaruhi jumlah kandungan $\mathrm{N}$ total dalam tanah dimana 
Widhiastuti et. al (2006) menyatakan bahwa pemberian LCPKS pada tanah areal perkebunan dapat meningkatkan $\mathrm{pH}$ tanah dari 5,39 menjadi $6,25, \mathrm{~N}$ total tanah meningkat sampai $46 \%$, $\mathrm{P}$ tersedia dari 7,778 ppm menjadi 224,78 ppm, $\mathrm{K}$ dari 0,098 me menjadi $0,962 \mathrm{me}, \mathrm{Mg}$ dari 0,326 me menjadi 2,563 me. Hal ini juga sesuai dengan pendapat Syarief (1986) dalam Tambunan (2016), pertumbuhan tinggi tanaman dipengaruhi oleh tersedianya unsur nitrogen yang cukup berperan dalam proses pembelahan sel. Nitrogen mempunyai peran utama untuk merangsang pertumbuhan tanaman secara keseluruhan dan khususnya pertumbuhan batang yang dapa memacu pertambahan tinggi tanaman.

Hakim et al. (1986) juga menyatakan terjadinya pertumbuhan tinggi dari suatu tanaman karena adanya peristiwa pembelahan sel dan perpanjangan sel yang didominasi pada pucuk tanaman tersebut. Proses ini memerlukan sintesa protein yang diperoleh tanaman dari lingkungan seperti bahan organik dalam tanah. Penambahan bahan organik yang mengandung $\mathrm{N}$ akan mempengaruhi kada $\mathrm{N}$ total dan dapat membantu mengaktifkan sel-sel tanaman dan mempertahankan jalannya proses fotosintesis yang pada akhirnya pertumbuhan tinggi tanaman dipengaruhi. Oleh karena itu untuk memperoleh pertumbuhan tanaman kelapa sawit yang baik unsur $\mathrm{N}$ harus cukup tersedia selama proses pertumbuhan.

\section{Pertambahan Jumlah Pelepah}

Tabel 2 menunjukkan bahwa pemberian LCPKS dosis 5,0 liter dengan satu lubang, dua lubang biopori, tiga lubang biopori, empat lubang biopori/tanaman meningkatkan jumlah pelepah sekitar dua sampai tiga kali dan peningkatannya lebih besar yaitu tiga sampai lima kali bila dosisnya ditingkatkan hingga 7,5 liter pada dosis 10,0 liter peningkatan jumlah pelepah cenderung menurun yaitu tiga sampai empat kali dibanding tanpa perlakuan.

Tabel 2. Pertambahan jumlah pelepah setelah pemberian LCPKS dengan metoda biopori pada umur 30 - 32 bulan

Dosis LCPKS dan lubang resapan biopori/tanaman

$\begin{gathered}\text { Pertambahan jumlah pelepah } \\ \text { (helai) }\end{gathered}$
$5,00 \mathrm{f}$
$13,33 \mathrm{~d}$
$15,00 \mathrm{cde}$
$15,33 \mathrm{cde}$
$16,33 \mathrm{cde}$
$18,00 \mathrm{bcd}$
$19,33 \mathrm{abc}$
$24,00 \mathrm{a}$
$22,33 \mathrm{ab}$
$20,00 \mathrm{abc}$
$17,66 \mathrm{bcd}$
$13,33 \mathrm{de}$

Tanpa perlakuan

LCPKS dosis 5,0 liter dengan 2 lubang biopori/tanaman

LCPKS dosis 5,0 liter dengan 3 lubang biopori/tanaman

LCPKS dosis 5,0 liter dengan 4 lubang biopori/tanaman

LCPKS dosis 7,5 liter dengan 1 lubang biopori/tanaman

LCPKS dosis 7,5 liter dengan 2 lubang biopori/tanaman

LCPKS dosis 7,5 liter dengan 3 lubang biopori/tanaman

LCPKS dosis 7,5 liter dengan 4 lubang biopori/tanaman

LCPKS dosis 10,0 liter dengan 1 lubang biopori/tanaman

LCPKS dosis 10,0 liter dengan 2 lubang biopori/tanaman

LCPKS dosis 10,0 liter dengan 3 lubang biopori/tanaman

LCPKS dosis 10,0 liter dengan 4 lubang biopori/tanaman

Angka-angka pada kolom yang diikuti oleh huruf kecil yang sama adalah berbeda nyata menurut uji DNMRT pada taraf 5\%.

Adapun pertambahan jumlah pelepah tertinggi diperoleh pada pemberian LCPKS dosis 7,5 liter dengan 4 lubang biopori/tanamn. Hal ini disebabkan karena kandungan unsur hara yang terdapat pada LCPKS yang dibutuhkan oleh tanaman telah terpenuhi.

Pemberian LCPKS dengan metoda biopori dapat meningkatkan jumlah pelepah karena unsur hara yang tergantung pada bahan 
organik sangat tinggi dan sangat diperlukan pada pertumbuhan dan perkembangan tanaman. Limbah cair pabrik pengolahan kelapa sawit mengandung unsur hara yang tinggi diantarnya adalah $\mathrm{Ca}$ (kalsium). Produksi pelepah akan semakin banyak seiring meningkatnya $\mathrm{Ca}$, pada TBM-1 peningkatan Ca dapat menyebabkan produksi 2.5 pelepah per bulan (Sudradjat et al., 2014).

Menurut Lubis (1992) bahwa pemberian bahan organik pada tanaman akan memberikan pengaruh yang baik bagi pertumbuhan tanaman, jika pemberian berlebihan akan menekan pertumbuhan tanaman. Pemberian LCPKS dengan metoda biopori pada tanaman kelapa sawit belum menghasilkan dapat menyebar dengan merata secara perlahan-lahan di sekitar tanaman sehingga dapat memperbaiki sifat-sifat tanah, menyediakan unsur hara dan dapat meningkatkan pertumbuhan tanaman. Hal ini sesuai dengan pendapat Tim Biopori IPB (2009) bahwa salah satu manfaat dari lubang resapan biopori yaitu menyuburkan tanaman, bahan organik yang kita berikan kedalam lubang resapan biopori merupakan makanan untuk organisme yang ada di dalam tanah. Organisme tersebut dapat mengubah bahan organik menjadi pupuk bagi tanaman di sekitarnya.

Fauzi (2002) juga menyatakan bahwa jumlah pelepah, panjang pelepah, dan anak daun tergantung pada umur tanaman. Jumlah pelepah berkaitan dengan tinggi tanaman, semakin banyak jumlah pelepah yang terbentuk maka tanaman akan semakin tinggi karena pelepah daun keluar dari nodus-nodus yakni tempat kedudukan daun yang ada pada batang (Harjadi, 1991). Selain itu menurut Fairhurst dan Harder (2003), sifat morfologi tanaman kelapa sawit juga berpengaruh terhadap jumlah pelepah, dimana rata-rata pertumbuhan pelepah kelapa sawit antara satu sampai tiga buah per bulan. Pahan (2011) menyatakan bahwa kondisi lingkungan yang lebih sesuai umumnya dapat mempercepat laju produksi daun sampai 24 daun selama 6 bulan di Papua Nugini.

\section{Pertambahan Panjang Pelepah}

Tabel 3 menunjukkan bahwa pemberian LCPKS dosis 5,0 liter dengan satu lubang, dua lubang, tiga lubang dan empat lubang biopori/tanaman meningkatkan panjang pelepah sekitar satu sampai dua kali dan peningkatannya lebih besar yaitu tiga sampai empat kali bila dosisnya ditingkatkan hingga 7,5 liter, pada dosis 10,0 liter peningkatan panjang pelepah cenderung menurun yaitu tiga kali dibanding tanpa perlakuan. Adapun pertambahan panjang pelepah tertinggi diperoleh pada pemberian LCPKS dosis 7,5 liter dengan 4 lubang biopori /tanaman. Hal ini disebabkan ketersediaan unsur hara yang terdapat pada LCPKS sangat dibutuhkan oleh tanaman kelapa sawit, khususnya pada tanaman kelapa sawit belum menghasilkan.

Panjang pelepah kesembilan menunjukkan luasan permukaan daun akan menangkap radiasi matahari sebagai bahan fotosintat untuk menunjang pertumbuhan dan produksi. Pelepah selama fase TBM dapat bertambah sebanyak satu sampai tiga pelepah setiap bulan sampai mencapai jumlah optimum.(Pahan, 2011).

Pemberian LCPKS dapat meningkatkan jumlah dan ketersediaan unsur hara $\mathrm{N}, \mathrm{P}, \mathrm{K}, \mathrm{Mg}$ dan $\mathrm{Ca}$ yang mendukung pertumbuhan tanaman. Selain unsur hara makro dan mikro LCPKS juga mengandung mikroorganisme pengurai. Menurut Hakim et al. (1986), peranan utama mikroorganisme adalah untuk merombak bahan organik menjadi bentuk senyawa yang dapat dimanfaatkan tanaman. Hal ini juga sejalan dengan pendapat Subowo (2010) bahwa bahan organik dapat memperbaiki sifat fisik tanah seperti struktur, aerase dan porositas tanah. Perbaikan sifat fisik tanah tersebut akan meningkatkan kemampuan tanah untuk menahan air. 
Tabel 3. Pertambahan panjang pelepah setelah pemberian LCPKS dengan metoda biopori pada umur 30-32 bulan

\begin{tabular}{lc}
\hline Dosis LCPKS dan lubang resapan biopori/tanaman & $\begin{array}{c}\text { Pertambahan panjang pelepah } \\
(\mathrm{cm})\end{array}$ \\
\hline Tanpa perlakuan & $8,66 \mathrm{~h}$ \\
LCPKS dosis 5,0 liter dengan 1 lubang biopori/tanaman & $12,33 \mathrm{~g}$ \\
LCPKS dosis 5,0 liter dengan 2 lubang biopori/tanaman & $13,33 \mathrm{~g}$ \\
LCPKS dosis 5,0 liter dengan 3 lubang biopori/tanaman & $14,66 \mathrm{~g}$ \\
LCPKS dosis 5,0 liter dengan 4 lubang biopori/tanaman & $19,00 \mathrm{f}$ \\
LCPKS dosis 7,5 liter dengan 1 lubang biopori/tanaman & $24,66 \mathrm{e}$ \\
LCPKS dosis 7,5 liter dengan 2 lubang biopori/tanaman & $29,66 \mathrm{bc}$ \\
LCPKS dosis 7,5 liter dengan 3 lubang biopori/tanaman & $31,33 \mathrm{ab}$ \\
LCPKS dosis 7,5 liter dengan 4 lubang biopori/tanaman & $34,00 \mathrm{a}$ \\
LCPKS dosis 10,0 liter dengan 1 lubang biopori/tanaman & $25,33 \mathrm{de}$ \\
LCPKS dosis 10,0 liter dengan 2 lubang biopori/tanaman & $28,00 \mathrm{~cd}$ \\
LCPKS dosis 10,0 liter dengan 3 lubang biopori/tanaman & $29,66 \mathrm{bc}$ \\
LCPKS dosis 10,0 liter dengan 4 lubang biopori/tanaman & $28,00 \mathrm{~cd}$ \\
\hline Anga-anga
\end{tabular}

Angka-angka pada kolom yang diikuti oleh huruf kecil yang sama adalah berbeda nyata menurut uji DNMRT pada taraf $5 \%$.

Hakim et al. (1986) menyatakan bahwa nitrogen, fospor dan kalium merupakan faktor pembatas karena pengaruhnya nyata bagi tanaman serta merupakan unsur hara yang paling banyak jumlahnya dibutuhkan tanaman Tingginya kandungan $\mathrm{N}$ pada pupuk organik mempunyai peran utama dalam pertumbuhan tanaman seperti pada pertambahan panjang pelepah, hal ini dijelaskan oleh Soepardi (1983), bahwa unsur hara $\mathrm{N}$ sangat di perlukan untuk pembentukan dan pertumbuhan bagianbagian vegetatif tanaman kelapa sawit.

\section{Pertambahan Lebar Anak Daun}

Tabel 4 menunjukkan bahwa pemberian LCPKS dosis 5,0 liter dengan satu lubang, dua lubang, tiga lubang, empat lubang biopori per tanaman meningkatkan lebar anak daun masing-masing yaitu $0,03 \mathrm{~cm}, 0,03 \mathrm{~cm}$, $0,03 \mathrm{~cm}$ dan $0,06 \mathrm{~cm}$. Pada dosis yang lebih tinggi $(7,5$ liter) diperoleh peningkatan pertambahan lebar anak daun masing-masing yaitu $0,1 \mathrm{~cm}, 0,13 \mathrm{~cm}, 0,1 \mathrm{~cm}$ dan $0,33 \mathrm{~cm}$. Namun, pada dosis 10,0 liter peningkatan lebar anak daun cenderung menurun masing-masing yaitu $0,16 \mathrm{~cm}, 0,06 \mathrm{~cm}, 0,03 \mathrm{~cm}$ dan $0,03 \mathrm{~cm}$ dibanding tanpa perlakuan. Adapun pertambahan lebar anak daun tertinggi diperoleh pada pemberian LCPKS dosis 7,5 liter denga 4 lubang biopori/tanaman.

Hal ini disebabkan karena aplikasi LCPKS serta lubang resapan biopori memberikan pengaruh yang baik untuk membentuk biopori dan memperbaiki sifat fisik, kimia dan biologi tanah, serta kebutuhan unsur hara dapat tersedia sehingga pertumbuhan vegetatif tanaman terutama pertambahan lebar anak daun meningkat. Hal ini sesuai dengan pendapat Tim Biopori IPB (2009), lubang resapan biopori diaktifkan oleh organisme tanah, khususnya fauna tanah dan perakaran tanah. Aktifitas organisme tanah tersebut selanjutnya akan menciptakan rongga-rongga atau liang-liang di dalam tanah.

Pertambahan lebar anak daun terendah terdapat pada tanpa perlakuan dan pemberian LCPKS dosis 5,0 liter untuk satu, dua, tiga dan empat unit lubang biopori. Hal ini diduga kandungan unsur hara yang terdapat pada LCPKS tersebut belum memenuhi kebutuhan tanaman dalam proses pertambahan lebar anak daun. Namun meskipun dilakukan peningkatan pemberiaan LCPKS dosisi 10,0 liter cenderung menurunkan pertambahan lebar anak daun, hal ini dikarenakan dosisi LCPKS sudah melebihi kebutuhan tanaman dalam proses pertumbuhan 
vegetatifnya sehingga pertumbuhan tanaman menjadi menurun. Sesuai dengan pendapat Salisbury dan Ross (1995) menyatakan jika dosis pupuk yang diberikan sudah mencapai kondisi yang optimal untuk pertumbuhan tanaman, meskipun dilakukan peningkatan dosis pupuk tidak akan memberikan pengaruh meningkat terhadap pertumbuhan dan perkembangan tanaman cenderung menurun.

Tabel 4. Rata-rata pertambahan lebar anak daun setelah pemberian LCPKS dengan metoda biopori pada umur 30-32 bulan

\begin{tabular}{lc}
\hline Dosis LCPKS dan lubang resapan biopori/tanaman & $\begin{array}{c}\text { Pertambahan lebar anak daun } \\
(\mathrm{cm})\end{array}$ \\
\hline Tanpa perlakuan & $0,10 \mathrm{c}$ \\
LCPKS dosis 5,0 liter dengan 1 lubang biopori/tanaman & $0,13 \mathrm{bc}$ \\
LCPKS dosis 5,0 liter dengan 2 lubang biopori/tanaman & $0,13 \mathrm{bc}$ \\
LCPKS dosis 5,0 liter dengan 3 lubang biopori/tanaman & $0,13 \mathrm{bc}$ \\
LCPKS dosis 5,0 liter dengan 4 lubang biopori/tanaman & $0,16 \mathrm{bc}$ \\
LCPKS dosis 7,5 liter dengan 1 lubang biopori/tanaman & $0,20 \mathrm{bc}$ \\
LCPKS dosis 7,5 liter dengan 2 lubang biopori/tanaman & $0,23 \mathrm{bc}$ \\
LCPKS dosis 7,5 liter dengan 3 lubang biopori/tanaman & $0,20 \mathrm{bc}$ \\
LCPKS dosis 7,5 liter dengan 4 lubang biopori/tanaman & $0,43 \mathrm{a}$ \\
LCPKS dosis 10,0 liter dengan 1 lubang biopori/tanaman & $0,26 \mathrm{~b}$ \\
LCPKS dosis 10,0 liter dengan 2 lubang biopori/tanaman & $0,16 \mathrm{bc}$ \\
LCPKS dosis 10,0 liter dengan 3 lubang biopori/tanaman & $0,13 \mathrm{bc}$ \\
LCPKS dosis 10,0 liter dengan 4 lubang biopori/tanaman & $0,13 \mathrm{bc}$ \\
\hline Angkangka
\end{tabular}

Angka-angka pada kolom yang diikuti oleh huruf kecil yang sama adalah berbedanyata menurut uji DNMRT pada taraf 5\%.

\section{Pertambahan Jumlah Anak Daun}

Tabel 5 menunjukkan bahwa pemberian LCPKS dosis 5,0 liter dengan satu lubang, dua lubang, tiga lubangdanempatlubangbiopori/tanamanmening katkan pertambahn jumlah anak daun berturutturut sebanyak 2,33 helai, 4,66 helai, 6 helai dan 6,66 helai. Pada dosis lebih tinggiyaitu 7,5 liter diperoleh peningkatan pertambahan jumlah anak daun masing-masing yaitu 9,66 helai, 11,0 helai, 16,0 helai dan 18,66 helai. Namun pada dosis 10,0 liter responnya relatif sama dengan pemberian dosis 7,5 liter dibanding tanpa perlakuan. Adapun pertambahan jumlah anak daun diperoleh pada pemberian LCPKS dosis 7,5 liter dengan 4 lubang biopori/tanaman. Hal ini menunjukkan bahwa pemberian LCPKS berkontribusi memperbaiki sifat-sifat tanah yaitu sifat fisika, kimia dan biologi sehingga dapat meningkatkan ketersediaan unsur hara yang dibutuhkan oleh tanaman.
Pemberian bahan organik dapat memperbaiki sifat fisik, biologi dan kimia tanah. Secara fisik bahan organik berpengaruh terhadap struktur tanah dan secara biologis merupakan sumber energi dan karbon bagi mikrobia heterotrofik serta secara kimia berperan dalam kapasitas pertukaran kation/anion sehingga berpengaruh penting terhadap ketersediaan hara tanah (Hanafiah, 2010)

Perbedaan pertambahan jumlah daun diduga unsur nitrogen, fosfor, kalium dan magnesium yang terkandung dalam LCPKS memberikan peran bagi pertumbuhan vegetatif tanaman kelapa sawit belum menghasilkan umur 30 bulan sampai 32 bulan terutama unsur hara nitrogen dengan kandungan 1,495 mg. $\mathrm{l}^{-1}$. Sesuai pendapat Lakitan (2000) menyatakan bahwa unsur hara yang sangat berpengaruh terhadap pertumbuhan dan perkembangan tanaman yaitu nitrogen, dimana konsentrasi nitrogen yang cukup akan menghasilkan daun 
yang baik, selain itu unsur nitrogen yang tinggi akan menghasilkan protein yang lebih banyak yang berperan dalam pembentukan protein. Ditambahkan oleh Jumin (1986) bahwa dengan adanya unsur hara nitrogen yang dapat mendorong pertumbuhan vegetatif diantaranya pembentukan klorofil pada daun sehingga akan memacu laju fotosintesis. Tanaman membutuhkan unsur hara untuk melakukan proses metabolisme, terutama pada masa pertumbuhan vegetatif. Unsur yang diserap dapat digunakan untuk mendorong pembelahan sel dan pembentukan sel-sel yang baru guna membentuk organ tanaman seperti daun, batang dan akar yang lebih baik sehingga dapat memperlancar proses fotosintesis ( Rizqiani et al., 2007).

Tabel 5. Rata-rata pertambahan jumlah anak daun setelah pemberian LCPKS dengan metoda biopori pada umur 30-32 bulan

\begin{tabular}{lc}
\hline Dosis LCPKS dan lubang resapan biopori/tanaman & $\begin{array}{c}\text { Pertambahan jumlah anak daun } \\
\text { (helai) }\end{array}$ \\
\hline LCPKS dosis 0 liter tanpa lubang biopori & $7,00 \mathrm{f}$ \\
LCPKS dosis 5,0 liter dengan 1 lubang biopori/tanaman & $9,33 \mathrm{ef}$ \\
LCPKS dosis 5,0 liter dengan 2 lubang biopori/tanaman & $11,66 \mathrm{ed}$ \\
LCPKS dosis 5,0 liter dengan 3 lubang biopori/tanaman & $13,00 \mathrm{~d}$ \\
LCPKS dosis 5,0 liter dengan 4 lubang biopori/tanaman & $13,66 \mathrm{~d}$ \\
LCPKS dosis 7,5 liter dengan 1 lubang biopori/tanaman & $16,66 \mathrm{c}$ \\
LCPKS dosis 7,5 liter dengan 2 lubang biopori/tanaman & $18,00 \mathrm{c}$ \\
LCPKS dosis 7,5 liter dengan 3 lubang biopori/tanaman & $23,00 \mathrm{~b}$ \\
LCPKS dosis 7,5 liter dengan 4 lubang biopori/tanaman & $25,66 \mathrm{a}$ \\
LCPKS dosis 10,0 liter dengan 1 lubang biopori/tanaman & $21,66 \mathrm{~b}$ \\
LCPKS dosis 10,0 liter dengan 2 lubang biopori/tanaman & $21,66 \mathrm{~b}$ \\
LCPKS dosis 10,0 liter dengan 3 lubang biopori/tanaman & $23,00 \mathrm{~b}$ \\
LCPKS dosis 10,0 liter dengan 4 lubang biopori/tanaman & $23,66 \mathrm{ab}$ \\
\hline Angka-angka & $\mathrm{nata}$ manat
\end{tabular}

Angka-angka pada kolom yang diikuti oleh huruf kecil yang sama adalah berbeda nyata menurut uji DNMRT pada taraf 5\%.

\section{Pertambahan Panjang Anak Daun}

Tabel 6 menunjukkan bahwa pemberian LCPKS dosis 5,0 liter dengan satu lubang, dua lubang, tiga lubang dan empat lubang biopori/tanaman meningkatkan jumlah pelepah sekitar dua sampai tiga kali dan peningkatannya lebih besar yaitu tiga sampai lima kali bila dosisnya ditingkatkan hingga 7,5 liter, pada dosis $\quad 10,0$ liter peningkatan lingkar batang cenderung menurun yaitu tiga sampai empat kali dibanding tanpa perlakuan. Adapun pertambahan panjang anak daun tertinggi diperoleh pada pemberian LCPKS dosis 7,5 liter dengan 4 lubang biopori/tanaman.

Aplikasi LCPKS pada tanaman dengan kandungan nitrogen $\left(1,495 \mathrm{mg} . \mathrm{l}^{-1}\right)$ yang ada didalamnya dapat dimanfaatkan tanaman kelapa sawit belummenghasilkan untuk pertumbuhan panjang anak daun. Hal ini sesuai dengan pendapat Sutarta et al. (2003) menyatakan bahwa unsur hara $\mathrm{N}$ mampu meningkatkan panjang dan lebar daun tanaman.

Pertambahan panjang anak daun dengan pemberian LCPKS juga diduga disebabkan karena lubang resapan biopori yang mengelilingi tanaman kelapa sawit berfungsi dengan baik membentuk biopori akibat aktifitas dari mikroorganisme pada tanah dan memperbaiki sifat fisik, biologi dan kimia tanah serta meningkatkan kesuburan tanah disekitar tanaman sehingga unsur hara yanng terdapat pada LCPKS terutama nitrogen dapat segera tersedia bagi tanaman dan dapat membantu pertambahan panjang daun. Sesuai dengan pendapat Brata (2008) bahwa dalam waktu 14 hari setelah pemberian bahan organik 
pada lubang resapan biopori, secara alami akan terbentuk biopori atau liang-liang memanjang dan bercabang-cabang didalam tanah akibat aktifitas cacing mikroorganisme lainnya.

Tabel 6. Pertambahan panjang anak daun (helai) setelah pemberian LCPKS dengan metoda biopori Dosis LCPKS dan lubang resapan biopori/tanaman Pertambahan panjang anak daun (helai)

Tanpa Perlakuan $5,00 \mathrm{f}$

LCPKS dosis 5,0 liter dengan 1 lubang biopori/tanaman $11,33 \mathrm{e}$

LCPKS dosis 5,0 liter dengan 2 lubang biopori/tanaman 13,00 ed LCPKS dosis 5,0 liter dengan 3 lubang biopori/tanaman 15,00 cde LCPKS dosis 5,0 liter dengan 4 lubang biopori/tanaman 15,33 cde

LCPKS dosis 7,5 liter dengan 1 lubang biopori/tanaman 16,33 cde LCPKS dosis 7,5 liter dengan 2 lubang biopori/tanaman LCPKS dosis 7,5 liter dengan 3 lubang biopori/tanaman $18,00 \mathrm{bcd}$ $19,33 \mathrm{abc}$ LCPKS dosis 7,5 liter dengan 4 lubang biopori/tanaman $24,00 \mathrm{a}$ LCPKS dosis 10,0 liter dengan 1 lubang biopori/tanaman $22,33 \mathrm{ab}$ LCPKS dosis 10,0 liter dengan 2 lubang biopori/tanaman $20,00 \mathrm{abc}$ LCPKS dosis 10,0 liter dengan 3 lubangbiopori/tanaman $17,66 \mathrm{bcd}$ LCPKS dosis 10,0 liter dengan 4 lubang biopori/tanaman 13,33 ed

Angka-angka pada kolom yang diikuti oleh huruf kecil yang sama adalah berbeda nyata menurut uji DNMRT pada taraf $5 \%$.

\section{KESIMPULAN}

Hasil penelitian menunjukkan bahwa aplikasi LCPKS dosis 7,5 liter dalam 4 biopori/tanaman meningkatkan penambahan jumlah pelepah dan daun, lebar dan panjang daun dibandingkan dengan tanpa LCPKS dan tertinggi dari perlakuan lain, tetapi penambahan tinggi tanaman pada aplikasi LCPKS dosis 7,5 liter dalam 3 biopori/tanaman dan tertinggi dari perlakuan lainnya.

\section{DAFTAR PUSTAKA}

Askrindayani, F. 2006. Penyebaran Unsur Hara dari Limbah Cair Pabrik Kelapa Sawit yang Diaplikasikan pada Tanah di Perkebunan Kelapa Sawit PT. Amal Tani. Skripsi (Tidak dipublikasikan). Universitas Sumatera Utara. Medan.

Brata, K. 2008. Lubang Resapan Biopori. Swadaya. Jakarta.

Direktorat Pengolahan Hasil Pertanian. 2006. Pedoman Pengelolaan Limbah Industri Kelapa Sawit. Deptan. Jakarta. 81 Hal
Fauzi, Y. 2002. Budidaya Pemanfaatan Hasil dan Limbah Analisis Usaha Tani dan Pemasaran. Penebar Swadaya. Jakarta.

Hanafiah, K. A. 2010. Dasar-Dasar Ilmu Tanah. PT. Raja Grafindo Persada. Jakarta.

Hakim, N., M. Y. Nyakpa, A. M. Lubis, S. G. Nugroho, M. R. Saul, M. A. Diha, G. B. Hong dan H. H. Bailey. 1986. Dasar-dasar Ilmu Tanah. Universitas Lampung. Lampung.

Harjadi, S. S. 1991. Pengantar Agronomi. PT Gramedia Pustaka Utama. Jakarta.

Jumin, H. B. 1986. Dasar-dasar Agronomi. Rajawali Press. Jakarta.

Lakitan, B. 2000. Dasar-dasar Fisiologi Tumbuhan. PT. Raja Grafindo Persada. Jakarta.

Lubis, A. U. 1992. Kelapa Sawit (Elaeis guineensis Jacq.) di Indonesia. Pusat 
Penelitian Marihat - Bandar Kuala. Pematang Siantar.

Ma.A.N. 2000. Management of palm oil industrial effluent. In. Basiron, Y., B.S. Jailani and k.w. Chan. Advances in oil palm research. Vol II. Malaysian palm oil board, Ministry of primary industrie, Malaysia.

Nainggolan, H. 2002. Pengolahan Limbah Cair Pabrik Kelapa Sawit. PT. Perkebunan Nusantara VI(Persero). Sumbar-Jambi.

Pahan, I. 2011. Panduan Lengkap Kelapa Sawit: Manajemen Agribisnis dari Hulu hingga Hilir. Penebar Swadaya. Jakarta.

Rizqiani, N., F.A. Erlina \& W.Y. Nasih. 2007. Pengaruh Dosis dan Frekuensi Pemberian Pupuk Organik Cair Terhadap Pertumbuhan dan Hasil Buncis. Jurnal Ilmu Tanah dan Lingkungan VII (1) : 43-45.

Salisbury, F. B. dan C. W. Ross. 1995. Fisiologi Tumbuhan Jilid I. Terjemahan DR Lukman. Penerbit ITB. Bandung. Hal 150-176.

Soepardi, G. 1983. Sifat dan Ciri Tanah. Institut Pertanian Bogor. Bogor
Subowo, G. 2010. Strategi efisiensi penggunaan bahan organik untuk kesuburan dan produktivitas tanah melalui pemberdayaan sumber daya hayati tanah. Jurnal sumber daya lahan. 4(1): $13-25$

Sutanto, R. 2006. Penerapan Pertanian Organik. Kanisius. Jakarta.

Sutarta, E. S., P. L. Tobing dan Sufianto. 2003. Aplikasi Limbah Cair Pabrik Kelapa Sawit pada Perkebunan Kelapa Sawit. Pertemuan Kelapa Sawit II. Medan. 13-14 Juni 2003.

Syarief, S. 1986. Kesuburan dan Pemupukan Tanaman Pertanian. Pustaka Buana. Bandung.

Tambunan, J. 2016. Aplikasi limbah cair pabrik kelapa sawit dengan metoda biopori terhadap pertumbuhan tanaman kelapa sawit (Elaeis guineensis Jacq.) Belum Menghasilkan. Skripsi (Tidak dipublikasikan). Universitas Riau. Pekanbaru.

Widhiastuti, R., D. Suryanto, Mukhlis, H. Wahyuningsih. 2006. Pengaruh pemanfaatan limbah cair pabrik kelapa sawit sebagai pupuk terhadap biodiversitas tanah. Jurnal Ilmiah Pertanian Kultura 41(1) 